\title{
-Original-
}

\section{Evaluation of Glycosaminoglycans Levels in Normal Joint Fluid of the Knee}

\author{
Yoshihito Nakayama, Yasumasa Shirai, Kiyoshi Yoshihara and Shinji Uesaka
}

Department of Orthopaedic Surgery, Nippon Medical School

\begin{abstract}
Glycosaminoglycans (GAGs) level in joint fluid have been investigated in various joint diseases as a joint maker. However, there are very few studies of normal joint fluid providing a baseline for a better understanding of altered GAGs level in pathological joint fluid. We investigated GAGs level in knee joint fluid for 25 healthy young volunteers with a mean age of 27.5 years (range: 18 to 36 years). Biochemical evaluations included the concentration of hyaluronic acid (HA), chondroitin 4-sulfate (C4S) and chondroitin 6-sulfate (C6S), and the $\mathrm{C} 6 \mathrm{~S} / \mathrm{C} 4 \mathrm{~S}$ ratio. The unsaturated disaccharides derived from HA by Morgan-Elson methods, and those from CS were measured with high performance liquid chromatography. The mean HA concentration was $3.4 \pm 0.6 \mathrm{mg} / \mathrm{ml}$. The mean concentration of $\mathrm{C} 4 \mathrm{~S}$ and $\mathrm{C} 6 \mathrm{~S}$, and $\mathrm{C} 6 \mathrm{~S} / \mathrm{C} 4 \mathrm{~S}$ ratio were $19.0 \pm 4.9 \mathrm{nmol} / \mathrm{ml}, 125.5 \pm 44.4$ $\mathrm{nmol} / \mathrm{ml}$ and $6.5 \pm 1.1$ respectively. (J Nippon Med Sch 2000; 67: 92-95)
\end{abstract}

Key words: hyaluronic acid, chondroitin sulfate, normal joint fluid, biochemical analysis

\section{Introduction}

Glycosaminoglycans (GAGs) in joint fluid consist of hyaluronic acid (HA), chondroitin sulfate (CS) and keratan sulfate (KS) isomers. These GAGs have an important role in the joint lubrication and cartilageous nutrition. Recently their concentrations have been thought to reflect joint tissue metabolism in normal and diseased states. GAGs levels have been invesigated in various joint diseases ${ }^{1.3}$, and considerable interest has been developing as a joint marker for rheumatoid arthritis (RA) and osteoarthritis (OA).

However, there have been some debates ${ }^{4.5}$ about whether GAGs levels in joint fluid increase or decrease in RA and OA, compared with those in normal subjects, because there are few studies of normal joint fluid. Our review of current published studies on nor- mal joint fluid reveals the following limitations: studies are small, few description regarding to subject selection, inadequate study population and discrepancy between the results of HA and CS concentration. To our knowledge, is no detailed study evaluating normal GAGs levels, especially CS levels in joint fluid. The aim of this study is to claryfy normal GAGs levels of joint fluid.

\section{Materials and Methods}

We examined joint fluid from healthy young volunteers with no history of knee symptoms and injuries. Moreover athlele participating high level sports was excluded from the present study. Sufficient volumes of joint fluid for assay $(0.2 \mathrm{ml})$ were obtained from 25 of 59 volunteers. The mean age of these 25 volunteers was 27.5 years (range: 18 to 36 years).

Corresponding to, Yoshihito Nakayama M.D., Department of Orthopaedic Surgery, Nippon Medical School, 1-1-5

Sendagi, Bunkyo-ku, Tokyo 113-8603, Japan

Journal Website (http://www.nms.ac.jp/jnms/) 
Table 1 The results of glycosaminoglycans levels of synovial fluid in 25 healthy young volunteers

\begin{tabular}{|c|c|c|c|c|c|c|c|}
\hline \multirow{2}{*}{ Case } & \multirow{2}{*}{ Age } & \multirow{2}{*}{ Sex } & Volume & HA & $\mathrm{C} 4 \mathrm{~S}$ & C6S & \multirow{2}{*}{$\mathrm{C} 6 \mathrm{~S} / \mathrm{C} 4 \mathrm{~S}$} \\
\hline & & & $\mathrm{m} l$ & $\mathrm{mg} / \mathrm{ml}$ & $\mathrm{nmol} / \mathrm{ml}$ & $\mathrm{nmol} / \mathrm{m} l$ & \\
\hline 1 & 26 & M & 0.5 & 3.3 & 15.2 & 75.8 & 5.0 \\
\hline 2 & 31 & $\mathrm{~F}$ & 0.5 & 4.4 & 16.3 & 100.7 & 6.2 \\
\hline 3 & 24 & M & 0.5 & 3.5 & 15.7 & 86.7 & 5.5 \\
\hline 4 & 36 & M & 0.5 & 4.2 & 19.1 & 102.2 & 5.4 \\
\hline 5 & 18 & $\mathrm{~F}$ & 0.8 & 3.9 & 21.7 & 157.6 & 7.3 \\
\hline 6 & 35 & M & 1.0 & 2.6 & 16.9 & 134.4 & 7.7 \\
\hline 7 & 35 & M & 0.3 & 3.6 & 25.2 & 139.7 & 5.5 \\
\hline 8 & 26 & $\mathrm{~F}$ & 0.5 & 3.4 & 18.1 & 80.3 & 4.4 \\
\hline 9 & 34 & M & 0.4 & 3.1 & 12.0 & 86.0 & 7.2 \\
\hline 10 & 35 & $\mathrm{~F}$ & 0.8 & 3.9 & 14.6 & 96.4 & 6.6 \\
\hline 11 & 26 & $\mathrm{~F}$ & 0.6 & 3.6 & 14.1 & 92.0 & 6.5 \\
\hline 12 & 21 & $\mathrm{~F}$ & 1.0 & 3.2 & 12.7 & 83.8 & 6.6 \\
\hline 13 & 26 & M & 0.3 & 3.4 & 18.4 & 134.3 & 7.3 \\
\hline 14 & 20 & M & 0.6 & 3.3 & 16.6 & 104.0 & 6.3 \\
\hline 15 & 22 & M & 1.0 & 3.8 & 20.9 & 153.1 & 7.3 \\
\hline 16 & 29 & M & 0.9 & 3.0 & 16.7 & 108.6 & 6.5 \\
\hline 17 & 22 & M & 1.3 & 3.5 & 29.7 & 214.4 & 7.2 \\
\hline 18 & 25 & M & 0.3 & 2.5 & 26.0 & 181.4 & 7.0 \\
\hline 19 & 28 & M & 0.3 & 2.7 & 22.9 & 219.1 & 9.6 \\
\hline 20 & 26 & M & 1.1 & 2.0 & 15.8 & 102.6 & 6.5 \\
\hline 21 & 28 & $\mathrm{~F}$ & 0.3 & 3.8 & 16.4 & 99.4 & 6.1 \\
\hline 22 & 23 & M & 0.4 & 4.4 & 27.7 & 218.3 & 7.9 \\
\hline 23 & 29 & $\mathrm{~F}$ & 0.3 & 3.4 & 17.6 & 107.6 & 6.1 \\
\hline 24 & 32 & M & 0.6 & 3.9 & 27.8 & 161.5 & 5.8 \\
\hline 25 & 31 & $\mathrm{~F}$ & 0.2 & 3.2 & 16.9 & 97.0 & 5.7 \\
\hline
\end{tabular}

$\mathrm{M}$ : male, F : female, HA : hyalunonic acid, C4S : chondroitin 4-sulfate, C6S : chondroitin 6-sulfate, $\mathrm{C} 6 \mathrm{~S} / \mathrm{C} 4 \mathrm{~S}$ : a ratio of $\mathrm{C} 6 \mathrm{~S}$ to $\mathrm{C} 4 \mathrm{~S}$

Joint fluid samples were collected in sterile plastic tubes and centrifuged at $10,000 \times \mathrm{g}$ for 15 minutes at $4^{\circ} \mathrm{C}$ to remove cells and joint debris. The supernatants were stored at $-80^{\circ} \mathrm{C}$ until biochemical assay. The unsaturated disaccharides derived from hyaluronic acid (HA) by Morgan-Elson methods ${ }^{6}$, and those from CS were measured by high performance liquid chromatography (HPLC $)^{7}$. Biochemical evaluations included the concentration of HA, chondroitin 4-sulfate (C4S), and chondroitin $6^{-}$sulfate $(\mathrm{C} 6 \mathrm{~S})$, and $\mathrm{C} 6 \mathrm{~S} / \mathrm{C} 4 \mathrm{~S}$ ratio.

\section{Results}

The results of GAGs levels of joint fluid in 25 healthy volunteers were shown in Table 1. The mean volume of joint fluid was $0.6 \pm 0.3 \mathrm{ml}$ (range: 0.2 to 1.3 $\mathrm{ml}$ ). The mean HA concentration was $3.4 \pm 0.6 \mathrm{mg} / \mathrm{ml}$ (range: 2.0 to $4.4 \mathrm{mg} / \mathrm{ml}$ ). The mean concentration of $\mathrm{C} 4 \mathrm{~S}$ and $\mathrm{C} 6 \mathrm{~S}$ were $19.0 \pm 4.9 \mathrm{nmol} / \mathrm{ml}$ (range: 12.0 to
$29.7 \mathrm{nmol} / \mathrm{ml}$ ) and $125.5 \pm 44.4 \mathrm{nmol} / \mathrm{ml}$ (range: 75.8 to $219.1 \mathrm{nmol} / \mathrm{ml}$ ) respectively. The mean $\mathrm{C} 6 \mathrm{~S} / \mathrm{C} 4 \mathrm{~S}$ ratio was $6.5 \pm 1.1$ (range: 4.4 to 9.6 ).

\section{Discussion}

The determination of GAGs in human joint fluid has been difficult due to diversity of structures and limited amount of unsaturated disaccaharides. Recently the development of HPLC allows more specific and sensitive determination of HA and CS isomers derived from GAG chains ${ }^{8,9}$.

$\mathrm{HA}$ is a main component of synovium and joint fluid. The viscoelastic property of joint fluid is mainly due to HA with a high capacity for binding water. Detection and quantitation of HA is of interest in many fields, especially in clinical chemistry. Recent studies demonstarted that HA has anti-inflammatory fuctions including inhibition of prostaglandin E2 synthesis ${ }^{10,11}$, 
suppression of leuckocyte migration and proliferation $^{12}$, and protection against cytotoxicity caused by reactive oxygen species ${ }^{13}$.

In normal condition, HA concentration in joint fluid is maintained at a higher level, comparing with blood level. In inflammatory diseases ${ }^{1-3}$ such as RA, gout and traumatic arthritis, HA concentration has been reported to be lower than normal. Balazs et al. ${ }^{14}$ stated that a considerable variation was found in HA concentration of joint fluid collected from various joints. They reported that HA concentration in joint fluid of the knee was $2.5 \sim 3.8 \mathrm{mg} / \mathrm{ml}$ in normal subjects aged 18 to 35 years. Our results for HA concentration agree well with their study.

CS contain a repeating disaccharides of N-acetylgalactosamine and glucuronate. In aggrecan ${ }^{15}$, most galactosamine residues carry a single sulphate group in 4 or 6 position, and a small portion are non-sulphated. Articular cartilage are rich in $\mathrm{CS}^{16}$, especially in C6S. Bayliss et al. ${ }^{17}$ reported that C6S makes up 72 $95 \%$ of $\mathrm{CS}$ in normal articular cartilage. $\mathrm{C} 4 \mathrm{~S}$ is distributed widely not only in articular cartilage, but also in synovium and ligament. Shinmei et al. ${ }^{18}$ stated that C6S in joint fluid derives mostly from articular cartilage because of its large tissues volume in the joint, and that $\mathrm{C} 6 \mathrm{~S}$ concentration and $\mathrm{C} 6 \mathrm{~S} / \mathrm{C} 4 \mathrm{~S}$ ratio may reflect cartilage metabolism.

Asari et al. ${ }^{19}$ reported in a study of 6 young volunteers that the mean concentrations of $\mathrm{C} 4 \mathrm{~S}$ and $\mathrm{C} 6 \mathrm{~S}$, $\mathrm{C} 6 \mathrm{~S} / \mathrm{C} 4 \mathrm{~S}$ ratio were $11.8 \pm 1.98 \mathrm{nmol} / \mathrm{ml}, 58.0 \pm 19.5$ $\mathrm{nmol} / \mathrm{ml}$ and 4.9 respectively. However no subject selection and detailed back ground data of study population were described in their study. Namiki ${ }^{20}$ noted in a study of 12 young athletes that the mean concentrations of $\mathrm{C} 4 \mathrm{~S}$ and $\mathrm{C} 6 \mathrm{~S}, \mathrm{C} 6 \mathrm{~S} / \mathrm{C} 4 \mathrm{~S}$ ratio and HA concentration were $14.8 \pm \mathrm{nmol} / \mathrm{ml}, 63.3 \pm 19.9 \mathrm{nmol} / \mathrm{ml}, 5.5 \pm$ 3.5 and $2.7 \pm 0.7 \mathrm{mg} / \mathrm{ml}$ respectively. These authors stated that questions remain about whether athletes are adequate for study population, and found that the results of HA concentration was lower compared with a study of Balazs et al. In comparison with their results, our results showed higher values for all three parameters. The reason for the discrepancy between these results is unclear, but may be mainly differences in subject selection or study population.

Change in CS concentration of joint fluid have been reported in various joint diseases. In recent studies, $\mathrm{C} 4 \mathrm{~S}$ and $\mathrm{C} 6 \mathrm{~S}$ concentrations and $\mathrm{C} 6 \mathrm{~S} / \mathrm{C} 4 \mathrm{~S}$ ratio in $\mathrm{RA}^{21,22}$ were reported to be $26.4 \sim 29.7 \mathrm{nmol} / \mathrm{ml}, 28.9 \sim$ $43.2 \mathrm{nmol} / \mathrm{ml}$ and $1.1 \sim 1.9$ respectively, and those in $\mathrm{OA}^{23-25} 15.4 \sim 20.4 \mathrm{nmol} / \mathrm{ml}, 56.8 \sim 81.1 \mathrm{nmol} / \mathrm{ml}$ and $3.8 \sim 4.0$. Judging from normal level obtained in the present study, in RA, C4S concentration considerablly increased and $\mathrm{C} 6 \mathrm{~S}$ concentration and $\mathrm{C} 6 \mathrm{~S} / \mathrm{C} 4 \mathrm{~S}$ ratio markedly decreased. In contast, in $\mathrm{OA}, \mathrm{C} 4 \mathrm{~S}$ concentration is similar to normal and $\mathrm{C} 6 \mathrm{~S}$ concentration C6S/C4S ratio are considerablly decreased. Shinmei et $\mathrm{al}^{26}$ noted that the proliferated synovium may accelerate the production and release of C4S into joint fluid, causing increased $\mathrm{C} 4 \mathrm{~S}$ concentration in RA, and loss of articular cartilage or an altered cartilage metabolism in RA and OA relate to decreased C6S concentration.

The present study demonstrates that GAGs level in normal joint fluid. Measurements of GAGs levels in joint fluid may provide useful information in monitoring joint tissue metabolism, and in assessing severity and the prognosis of joint diseases.

\section{References}

1. Lohmander LS: Markers of cartilage metabolism in arthrosis: a review. Acta Orthop Scand 1991; 62: 623632.

2. Caterson B, Hughes CE, Roughley P, Mort JS: Anabolic and catabolic markers of proteoglycan metabolism in osteoarthritis. Acta Orthop Scand 1995; 66: 121-124.

3. Hardingham $\mathrm{T}$ : Changes in chondroitin sulphate structure induced by joint disease. Acta Orthop Scand 1995; 66: 107-110.

4. Caterson B, Mahmoodian F, Sorrell JM, Hardingham TE, Bayliss MT, Carney SL: Modulation of native chondroitin sulphate structure in tissue development and in disease. Journal Cell Science 1990; 97: 411-417.

5. Brown MP, West LA, Merritt KA, Plaas AHK: Changes in sulfation patterns of chondroitin sulfate in equine articular cartilage and synovial fluid in response to aging and osteoarthritis. AJVR 1998; 59: 786-791.

6. Huang Y, Toyoda H, Toida T, Imanari T: Determination of chondroitin sulphates in human whole blood, plasma and blood cells by high-performance liquid chromatography. Biomedical Chromatography 1995; $9: 102-105$.

7. Bayliss MT, Davidson C, Woodhouse SM, Osborne DJ: Chondroitin sulphation in human joint tissues varies with age, zone and topography. Acta Orthop Scand 
1995; 66: 22-25.

8. Sandy JD, Flannery CR, Neame PJ, Lohmander LS: The structure of aggrecan fragments in human synovial fluid. J Clin Invest 1992; 89: 1512-1516.

9. Mourao PAS: Distribution of chondroitin 4-sulfate and chondroitin 6-sulfate in human articular and growth cartilage. Arthritis Rheum 1988; 31: 1028-1033.

10. Murakami K, Shibata T, Kubota E, Maeda H: Intraarticular levels of prostaglandin $\mathrm{E}_{2}$, hyaluronic acid, and chondroitin- 4 and -6 sulfates in the temperomandibular joint synovial fluid of patients with internal derangement. J Oral Maxillofac Surg 1998; 56: 199-203.

11. Yasui T, Akatsuka M, Tobetto K, Hayaishi M, Ando T: The effect of hyaluronan on interleukin- $1 \alpha$-induced prostaglandin $\mathrm{E}_{2}$ production in human osteoarthritic synovial cells. Agents Actions 1992; 37: 155-156.

12. Smith GN, Myers SL, Brandt KD, Mickler EA: Effect of intraarticular hyaluronan injection in experimental canine osteoarthritis. Arthritis and Rheumatism 1998; 41: 976-985.

13. Engstrom-Laurent A, Hallgren R: Circulating hyaluronic acd levels vary with physical activity in healthy subjects and in rhematoid arthritis patients: Relationship to synovitis mass and morning stiffness. Arthritis and Rheumatism 1987; 30: 1333-1338.

14. Balazs EA: The physical properties of synovial fluid and the special role of hyaluronic acid. "Disorders of the Knee” (Helfet AJ), 1982; pp 61-74 J.B. Lippincott.

15. Rizkalla G, Reiner A, Bogoch E, Poole AR: Studies of the articular cartilage proteoglycan aggrecan in health and osteoarthritis. J Clin Invest 1992; 90: 22682277.

16. Plaas AHK, West LA, Wong-Palms S, Nelson FRT: Glycosaminoglycan sulfation in human osteoarthritis 1998; 273: 12642-1269.

17. Bayliss MT, Osborne D, Woodhouse S, Davidson C: Sulfation of chondroitin sulfate in human articular cartilage. J Biol Chem 1999; 274: 892-900.

18. Shinmei M, Miyauchi S, Machida A, Miyazaki K: Quantitation of chondroitin 4-sulfate and chondroitin 6-sulfate in pathologic joint fluid. Arthritis Rheum 1992; 35: 1304-1308.

19. Asari A, Miyauchi S, Sekiguchi T, Machida A, Kuriyama S, Miyazaki K: Hyaluronan, cartilage destruction and hydrarthrosis in traumatic arthritis. Osteoarthritis and cartilage 1994; $2: 79-89$.

20. Namiki O: Composition and metabolism of normal synovial fluid. Joint Surjery 1996; 15: 31-39. (in Japanese).

21. Sato M, Kasai T, Takemura M, Noma A, Takeuti S: Analysis of synovial fluid in patients with osteoarthritis and rheumatoid arthritis. Cental Jpn J Orthop Surg Traumatol 1995; 38: 199-120. (in Japanese).

22. Ueyoshi A, Kiura Y: Quatitation of synovial fluid in the rhematoid arthritis and osteoarthritis: analysis of chondrotin sulfate content. Joint Surgery 1997; 24: 124-127. (in Japanese).

23. Lewis S, Crossman M, Flannelly J, Doherty M, Bayliss M, Mason R: Measurement of chondroitin sulphate disaccharides in pathological joint fluids. Acta Orthop Scand 1995; 66: 157-158.

24. Miyamoto K, Kozuka K, Kikuike A, Itozu M, Matsunaga T: Analysis of the synovial fluid in patients with osteoarthritis of knee joint in the point of OA-grade and daily activity patterns. Cental Jpn J Orthop Surg Traumatol 1995; 38: 121-122. (in Japanese).

25. Uesaka S, Nakayama Y, Fujii N, Kitta M, Yoshihara K, Shirai Y, Kaji K: Chondrosulfate level in synovial fluid on osteoarthritis of the knee. Joint Surgery 1998; 25: 58. (in Japanese).

26. Shinmei M, Kobayashi T, Yoshihara Y, Samura A: Significance of the levels of carboxy terminal typeII procollagen peptide, chondroitin sulfate isomers, tissue inhibitor of metalloproteinases, and metalloproteinases in osteoarthritis joint fluid. J Rheumatol 1995; 22: 7881.

(Received, November 8, 1999)

(Accepted, December 8, 1999) 